\title{
ADDITIONAL SYSTEMATIC INFORMATION ON THE EARLY CARBONIFEROUS PALYNOFLORA FROM THE AMBO FORMATION, PONGO DE MAINIQUE, PERU
}

\author{
CARLOS L. AZCUY \& MERCEDES DI PASQUO \\ CONICET, Department of Geology, Universidad de Buenos Aires, Ciudad Universitaria, Pabellón 2, (1428) \\ Buenos Aires,Argentina.azcuy@ciudad.com.ar,medipa@gl.fcen.uba.ar
}

\begin{abstract}
Palynologic results presented in this contribution come from six productive samples located in the upper part of the Ambo Formation at Pongo de Mainique, Peru. A brief geologic information and an annotated species list (some illustrated) including taxonomic and morphologic remarks for some taxa (genera or species) and their stratigraphic and geographic occurrences outside Peru, are displayed herein. The lectotype of Verrucosisporites nitidus Playford is here designed. The composition of the palynoflora allows correlating to the Cordylosporites magnidictyus Palynozone (late Viséan of the Amazon Basin, Brazil). More information such as the complete and illustrated list of taxa, are part of a recent publication on the palynology of the same unit realised by the same authors.
\end{abstract}

Key words: Systematic, occurrences, Ambo Formation, Early Carboniferous, Peru.

\begin{abstract}
RESUMO - Os dados palinológicos apresentados nesta contribuição foram obtidos a partir de seis amostras férteis procedentes da parte superior da Formação Ambo, na localidade de Pongo de Mainique, Peru. Uma síntese das informações geológicas e a lista de espécies registradas, algumas das quais ilustradas, são apresentadas, bem como comentários morfológicos e taxonômicos de alguns táxons e sua distribuição geográfica e estratigráfica fora do Peru. É designado o lectótipo de Verrucosisporites nitidus Playford. A composição da palinoflora permite correlação com a Palinozona Cordylosporites magnidictyus (Viseano final da bacia do Amazonas, Brasil). A lista completa de táxons, suas ilustrações e outras informações adicionais são parte de uma publicação recente sobre o tema realizada pelos autores.
\end{abstract}

Palabras-chave: Sistemática, ocorrências, Formação Ambo, Carbonífero inicial, Peru.

\section{INTRODUCTION}

Publications on palynology of Late Palaeozoic sequences of Peru are scarce (e.g., Wood et al., 2002; Azcuy et al., 2002; Azcuy \& di Pasquo, 2005). This work is part of a major research that attempts to increase the palaeontological knowledge of Late Palaeozoic sequences in southern South America in the framework of projects that allow work in collaboration with other palaeontologists. This is the second contribution on Early Carboniferous palynofloras from Peru and it is an addition to the first one recently published (Azcuy \& di Pasquo, 2005). This paper aims to complete the systematic analysis of a late Viséan palynoflora in Peru, to discuss the correlation with other stratigraphic units dated by palaeontologic means and to confirm once again that international (Euramerican) and Western Gondwanan (mainly derived from Brazilian and Argentinian basins) miospore zonal schemes, can be successfully applied to the dating of Carboniferous rocks of this region.

\section{MATERIAL AND METHODS}

A significant number of palynological samples were collected throughout the Ambo Formation; six of them yielded palynomorphs from the upper most part, last 100 $\mathrm{m}$ (Azcuy \& di Pasquo, 2005). The state of preservation of the miospores varies from highly carbonized to good or excellent. Standard methods of palynomorph recovery have been used. The slides have been housed with sample numbers from the Laboratory of Palynology of Petroperú S.A., in the Laboratory of Palynology, Department of Geology, University of Buenos Aires, Argentina. Palynomorph identifications were made using a Leitz Orthoplan binocular transmitted light microscope $\mathrm{N}^{\circ}$ 871080 , with $1000 x$ maximum magnification. The photomicrographs were taken with a Pixera digital camera. Coordinates of specimens are denoted by an England Finder (EF) reference. 


\section{BRIEF GEOLOGIC INFORMATION}

The palynologic results presented in this contribution come from six productive samples located in the upper part of the Ambo Formation at Pongo de Mainique $\left(12^{\circ} 20^{\prime} \mathrm{S}, 72^{\circ}\right.$ $\left.50^{\prime} \mathrm{W}\right)$, Peru. This locality displays one of the most complete sedimentary sequences, ranging in age from Silurian to Tertiary, located in the Andean Range, about $450 \mathrm{~km}$ to the east of Lima and $160 \mathrm{~km}$ to the northwest of Cusco. The Upper Palaeozoic sedimentary rocks present in the Madre de Dios Basin are mainly siliciclastic in the Early Carboniferous and calcareous sediments appear in the Late Carboniferous and increase to the Permian. The Upper Palaeozoic sequence in this region is subdivided into four formational units that in ascending stratigraphic order are: Ambo, Tarma, Copacabana and Ene Formations (see Azcuy \& di Pasquo, 2005).

The Ambo Formation at the Pongo de Mainique is $822 \mathrm{~m}$ thick, and it unconformably overlies Devonian rocks of the Cabanillas Formation. It consists mainly of light grey, finegrained sandstones and subordinated medium to coarsegrained and slightly carbonaceous and hard micaceous units. These fine to coarse-grained layers have internal crossstratification with lenticular geometry, and alternate with subordinate siltstones, light to dark grey lutites, sometimes with abundant pyrite, and thin laminated mudstone layers. A very thick bed of light grey, pebbly sandstone with rounded clasts and pyrite, showing internal cross-stratification, constitutes the base of the unit. Plant remains and calcareous deposits were not recorded at this locality.

The Tarma Formation (237 m thick), conformably overlies the Ambo Formation and is overlain by the Copacabana Formation. At the top of the Tarma Formation, the Illinites unicus Palynozone is recorded, which is considered to be Late Westphalian in age (Azcuy et al., 2002). The Copacabana Formation consists mainly of $647 \mathrm{~m}$, light to dark grey, micritic to bioclastic, compact limestones, containing fusulinids, brachiopods, pelecypods, bryozoans, and abundant fragments of fossils and chert nodules, in medium to thick beds. Interbedded, are dark grey calcareous claystones, and light grey to brown dolostones in thin to medium layers. Their basal and upper contacts are conformable. Recently, Wood et al. (2002) analyzed palynomorphs and microfossils from this unit and assigned an "Early-Middle" Pennsylvanian age. Above the Copacabana Formation, the Ene Formation is $168 \mathrm{~m}$ and consists mainly of subordinated limestones and dolostones interbedded within shales and sandstone layers. The upper contact with the Oriente Group (Cretaceous) is unconformable.

\section{ANNOTATED LIST OF MIOSPORES}

An annotated species list including taxonomic and morphologic remarks for some taxa (genera or species) and their stratigraphic and geographic occurrences outside Peru, is presented. The species are arranged in taxonomic order, although suprageneric categories are not cited. The references cited in occurrence sections include detailed systematic works and those with illustrated lists of species. Synonymies are only provided if not previously published. Rules given in the lastest edition of the ICBN in its Spanish version (Kiesling, 2002) are here adopted for the treatment of form taxa. Morphological terminology adopted herein is mainly in accordance with the last glossary provided by Punt et al. (1994). The reference list includes only the works cited in the remarks, synonymy lists and occurrences.

\section{Waltzispora lanzonii Daemon 1974}

(Figure 1A)

Occurrence. Early Carboniferous of Brazil (Daemon, 1974; Melo et al., 1999).

Waltzispora polita (Hoffmeister, Staplin \& Malloy) Smith \& Butterworth 1967

Leiotriletes politus Hoffmeister et al.; Menéndez \& Azcuy, 1969 :80, pl. 1: figs. A, B.

Leiotriletes politus Hoffmeister et al.; González Amicón, 1973:11, pl. I, fig. 2.

Occurrence. Widely recorded in microfloras from Early to Late Carboniferous rocks of South America, North America, Australia, Africa and Europe (Playford, 1991; di Pasquo, 2002).

Punctatisporites lucidulus Playford \& Helby 1968

Punctatisporites resolutus Playford; Souza et al., 1997, pl. I, fig. 2. Occurrence. Late Carboniferous of Argentina (Gutiérrez \& Césari, 1988), Brazil (Souza et al., 1997), Australia (Playford \& Helby, 1968; Jones \& Truswell, 1992).

\section{Retusotriletes anfractus Menéndez \& Azcuy 1969}

Occurrence. It is a very common component of Late Carboniferous microfloras from Argentina, and recently, it was also recorded in the Itararé Subgroup of Brazil (di Pasquo et al., 2003).

Retusotriletes crassus Clayton in Clayton, Johnston, Sevastopulo \& Smith 1980

(Figure 1B)

Retusotriletes sp. A Higgs, 1975:395, pl. 1, figs. 9, 13. Retusotriletes sp. A Higgs; Keegan, 1977:548, pl. 1 figs. 4, 5. Retusotriletes sp. A Higgs; Clayton et al., 1977:7, pl. 6 fig. 4. Retusotriletes sp. A Higgs; Utting, 1987a:79, pl. 2, fig. 11. Occurrence. Late Devonian-Early Carboniferous of Europe (Higgs, 1975; Keegan, 1977; Van der Zwan, 1980a; Keegan \& Feehan, 1981). Tournaisian-Viséan of Europe (Clayton et al., 1977; Higgs et al., 1988; Graham \& Clayton, 1994), Canada (Utting, 1987a; Utting et al., 1989a), Saudi Arabia (Clayton, 1995).

Apiculiretusispora semisenta (Playford) Massa, Coquel, Loboziak \& Taugourdeau-Lantz 1980

(Figure 1C) 

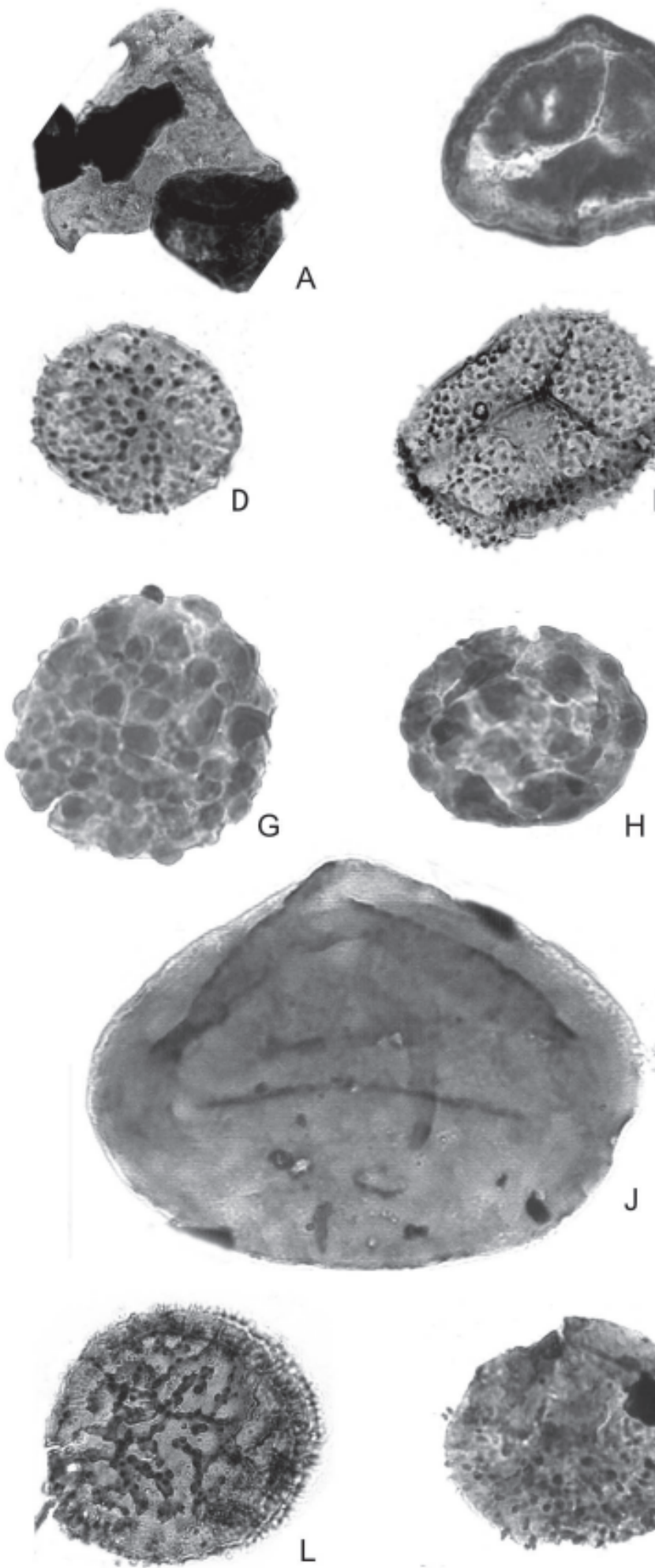

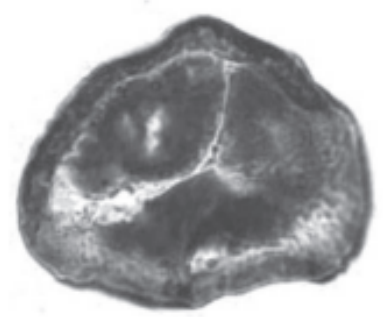

B
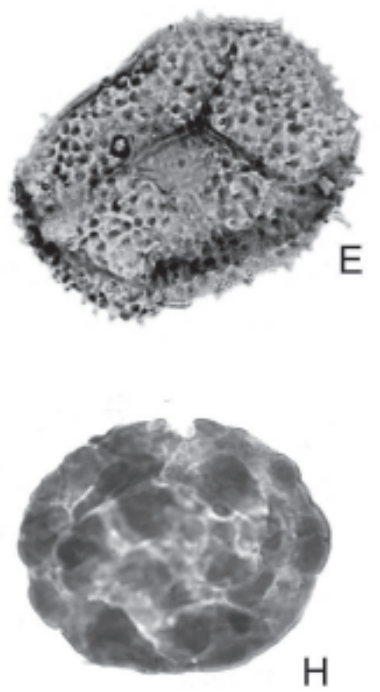

$\mathrm{H}$

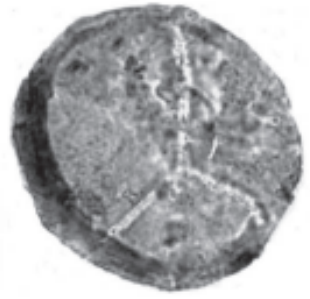

C

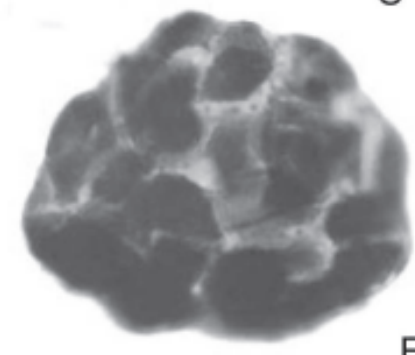

$\mathrm{F}$
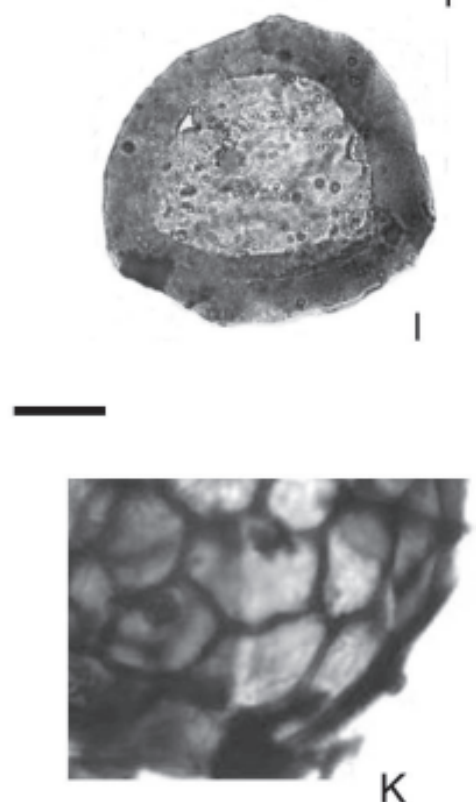

$\mathrm{K}$



Figure 1. Selected miospores from the Ambo Formation (in parenthesis are the slide number and the England Finder coordinate). A, Waltzispora lanzonii (1039, S54/3); B, Retusotriletes crasus (1043, Q51); C, Apiculiretusispora semisenta (1039, P43/3); D, Anapiculatisporites cf. A. austrinus (1043, Q52/4); E, Dibolisporites microspicatus (1037, O33/2); F, Verrucosisporites congestus (1035, W62); G, Verrucosisporites nitidus (1037, E54/2-4); H, Convolutispora insulosa (1039, P46); I, Densosporites anulatus (1037, Q33/1-3); J, Schopfipollenites ellipsoides (1043, U36/3); K, Cordylosporites magnidictyus (1035; N41/1); L, Cristatisporites peruvianus (1039, D29/4); M, Schofites claviger (1043, M51/4); N, Velamisporites minutus (1043, P66/3). Scale bar = $10 \mathrm{~mm}$ in K; scale bar $=15 \mathrm{~mm}$ in A-J, L-N 
Occurrence. Early Carboniferous of Argentina (Césari \& Limarino, 1995), Bolivia (Azcuy \& Ottone, 1987), Brazil (Melo \& Loboziak, 2000), Australia (Playford, 1971, 1978; 1985; Playford \& Satterthwait, 1986), Algeria (Attar et al., 1980), Libya (Massa et al., 1980), Niger (Loboziak \& Alpern, 1978; Coquel et al., 1995), Egypt (Kora, 1993).

\section{Granasporites medius (Dybová \& Jachovicz) Ravn, Butterworth, Phillips \& Peppers 1986}

Cyclogranisporites sp. di Pasquo et al. 2003:284, pl. 3, fig. G. Remarks. It is noted that some specimens of Granasporites medius (Dybová \& Jachowicz) Ravn et al. (1986) from Peru show reduced ornamentation on the proximal face, and occasionally the presence of gemmae and clavae that are mainly seen at the margin of the spore. The scarce elements on the proximal face are clumped close to the laesurae in some specimens. Additionally, the revision of more specimens of this species previously recorded from the Tupambi Formation (Argentina; di Pasquo, 2002) allowed reassigning Brazilian material from the Itararé Subgroup (di Pasquo et al., 2003) to this taxon.

Occurrence. Late Carboniferous of Argentina (di Pasquo, 2002), Brazil (di Pasquo et al., 2003). For previous records in U.S.A. and Europe see Ravn et al. (1986).

\section{Cyclogranisporites australis Azcuy 1975}

Occurrence. Early Late Carboniferous of Argentina (Azcuy, 1975).

Anapiculatisporites cf. A. austrinus Playford \& Satterthwait 1986 (Figure 1D)

Remarks. The species assignment is tentative because the Peruvian specimens have indistinct laesurae without lips and curvatures.

Occurrence. Viséan of Australia (Playford \& Satterthwait, 1986), Argentina (Césari \& Limarino, 1992).

\section{Dibolisporites microspicatus Playford 1978}

(Figure 1E)

Remarks. Dibolisporites disfacies Jones \& Truswell 1992, differs from D. microspicatus Playford mainly because in the latter the ornamentation is never discrete and evenly spaced.

Occurrence. Visean of Australia (Playford, 1978; Playford \& Satterthwait, 1986), Argentina (Césari \& Limarino, 1992).

\section{Verrucosisporites congestus Playford 1964}

(Figure 1F)

Occurrence. Early Carboniferous of Argentina (Césari \& Limarino, 1992, 1995), Brazil (Melo \& Loboziak, 2000, 2003), Canada (Playford, 1964; Smith, 1971; Utting, 1987a; Utting et al., 1989a), Ireland (Van der Zwan, 1980a; Van Veen, 1981; Higgs et al., 1988; Turnau et al., 1994).

\section{Verrucosisporites depressus Winslow 1962}

Occurrence. Early Carboniferous of U.S.A. (Winslow, 1962), Poland (Turnau, 1978; Turnau et al., 1994), Ireland (Van der Zwan, 1980a; Van Veen, 1981), Brazil (Melo \& Loboziak, 2000).

Verrucosisporites morulatus (Knox) Potonié \& Kremp 1955 emend. Smith \& Butterworth 1967

Verrucosisporites nodosus Sullivan \& Marshall, 1966:269, pl. 1, figs. 20, 21.

Remarks. The ornamentation is regular in size and distribution, with elements possessing more or less parallel sides. Elements display variable separation although occasionally may appear fused. The differences in the total diameter, mentioned by Sullivan \& Marshall (1966) to establish $V$. nodosus as a new species, must be discarded because Smith (1971) found that $V$. morulatus displays a size range of 30-80 $\mathrm{mm}$, which accomodates $V$. nodosus.

Occurrence. Early Carboniferous of Europe (Butterworth \& Williams, 1958; Neves, 1961; Sullivan \& Marshall, 1966; Smith \& Butterworth, 1967; Smith, 1971), Canada (Utting, 1987b), Egypt (Kora, 1993).

\section{Verrucosisporites nitidus Playford 1964}

(Figure 1G)

Lectotype. Verrucosisporites nitidus Playford, 1964:13, pl. 3, fig. 6 (designated herein).

Remarks. Turnau et al. (1994:290) examined the type material of Lophotriletes grumosus Naumova (1953) and found that the proximal face is laevigate. Therefore, it was separated from Verrucosisporites nitidus and it was stated in the text that one specimen amongst the four illustrated by Playford (1964) would be selected as the lectotype but finally, none was proposed. This task is here resolved by proposing as lectotype the specimen figured in Playford (1964, pl. 3, fig. 6). Occurrence. Latest Devonian-Early Carboniferous of Brazil (Melo et al., 1999; Melo \& Loboziak, 2003), Australia (Playford, 1976, 1985; Playford et al., 1976), Europe (Sullivan, 1964; Utting \& Neves, 1971; Keegan, 1977; Van der Zwan, 1980a; Van Veen, 1981; Higgs et al., 1988; Loboziak et al., 1994), Russia (Avchimovitch et al., 1988). Early Carboniferous of Bolivia (Azcuy \& Ottone, 1987; Vavrdová et al., 1993), Brazil (Loboziak et al., 1991; Melo \& Loboziak, 2000), Europe (Neves \& Ioannides, 1974; Higgs, 1975, 1996; Streel, 1977; Owens et al., 1977; Clayton et al., 1978; Turnau, 1978; Phillips \& Clayton, 1980; Higgs \& Clayton, 1984; Higgs et al., 1992; Graham \& Clayton, 1994), USA (Clayton et al., 1998), Alaska (Ravn, 1991), Australia (Playford, 1971, 1978, 1985; 1988, 1991; Playford \& Satterthwait, 1986), Canada (Playford, 1964; Utting, 1980, 1987a, 1987b; Utting et al., 1989a), Libya (Massa et al., 1980), Niger (Coquel et al., 1995), Saudi Arabia (Clayton, 1995), Egypt (Kora, 1993). For other previous records see Playford (1991).

Verrucosisporites perverrucosus (Loose) Potonié \& Kremp 1955 emend. Smith 1971 
Occurrence. This species has been reported from the Early to Late Carboniferous of Europe (Smith, 1971).

Verrucosisporites verrucosus (Ibrahim) Ibrahim 1933

Tuberculatisporites gigantonodatus Dybová \& Jachowicz, 1957:116, pl. 27, figs. 1-4.

Occurrence. Early Carboniferous of Canada (Utting, 1987b). Late Carboniferous of Argentina (di Pasquo et al., 2001), Europe (Smith \& Butterworth, 1967), U.S.A. (Peppers, 1970). For Early Permian records of Uruguay and Brazil see di Pasquo et al. (2001).

\section{Genus Schopfites Kosanke 1950}

Remarks. The generic diagnosis states that the contact areas lack ornamentation, distinguishing it from Raistrickia Schopf et al. 1944. Indeed, the original description of Raistrickia, later amended by Potonié \& Kremp (1954), suggests that the sculpture is distributed on both faces like in all or almost all the known species of this genus.

\section{Schopfites claviger Sullivan 1968}

(Figure 1M)

Schopfites delicatus Higgs, 1975:396-397, pl. 2, figs. 6, 7. Schopfites cf. S. delicatus Higgs et al., 1988:60, pl.5, fig.9, 14. Discussion. In this work the criterion of Playford \& Satterthwait (1986) to assign this species to the genus Raistrickia is not followed because of the absence of sculpture over almost all the proximal face. Besides, in accordance with Playford (1991), the amendments proposed by Higgs et al. (1988) for Schopfites claviger Sullivan (1968) and S. delicatus Higgs (1975) are not accepted herein. The mentioned species, including also $S$. cf. delicatus Higgs et al. (1988), display a gradational ornamentation, as shown in Higgs et al. (1988, fig. 30). Therefore, in order to avoid an artificial separation of these forms, they are considered herein as one same taxon. Ceratosporites delicatus (Higgs) Van der Zwan 1980 is rejected herein because it lacks a description and the illustration does not show ornamentation on the equator of the spore, a feature mentioned in the diagnosis of the species.

Occurrence. Early Carboniferous of Brazil (Loboziak et al., 1991, 1998; Melo \& Loboziak, 2003), Europe (Sullivan, 1968; Neves \& Belt, 1971; Neves et al., 1972, 1973; Neves \& Ioannides, 1974; Higgs, 1975; Owens et al., 1977; Clayton et al., 1977, 1978; Turnau, 1978; Higgs \& Clayton, 1984; Higgs et al., 1988; Clayton \& Turnau, 1990; Avchimovitch \& Turnau, 1994), Canada (Utting, 1987b; Utting et al., 1989a), Australia (Playford, 1971, 1991; Playford \& Satterthwait, 1986), Morocco (Loboziak et al., 1990). For other previous records see Playford (1991).

\section{Convolutispora insulosa Playford 1978}

(Figure 1H)

Verrucosisporites sp. cf. V. gobbettii Playford; Ravn, 1991:100, pl. 4, fig. 10.

Remarks. The absence or scarcity of sculptural elements on the contact areas and the lack of anastomosing ornamentation characterize this species.

Occurrence. Viséan of Australia (Playford, 1978; Playford \& Satterthwait, 1985), Alaska (Ravn, 1991).

\section{Convolutispora oppressa Higgs 1975}

Remarks. This species is characterized by a verrucose ornamentation, which to a large extent is fused to form rugulae that meet and anastomose without defining a true reticulum. The presence of rugulae prevents its assignment to the genus Verrucosisporites, in accordance with Higgs et al. (1988).

Occurrence. Strunian of Libya (Massa \& Moreau-Benoit, 1985). Late Devonian - Early Carboniferous of Europe (Higgs, 1975; Higgs et al., 1988; Loboziak et al., 1994), Bolivia (Vavrdová et al., 1993).

\section{Convolutispora $\mathrm{cf}$. C. elimata Playford 1978}

Occurrence. Viséan of Australia (Playford, 1978; Playford \& Satterthwait, 1985).

\section{Convolutispora cf. C. varicosa Butterworth \& Williams 1958}

Remarks. The Peruvian specimens differ from the original material and others recorded by Smith \& Butterworth (1967) and Playford \& Satterthwait (1988) only by their smaller size. Occurrence. Visean-Namurian A of Europe (Butterworth \& Williams, 1958; Smith \& Butterworth, 1967), Australia (Playford \& Satterthwait, 1988).

Cordylosporites magnidictyus (Playford \& Helby) Melo \& Loboziak 2000

(Figure 1K)

Remarks. In spite of the scarce and incomplete specimens recorded in the Peruvian samples, it was possible to recognize the diagnostic characters to justify its specific allocation.

Occurrence. Viséan of Brazil (Loboziak et al., 1998; Melo et al., 1999; Melo \& Loboziak, 2000, 2003), Australia (Playford \& Helby, 1968). Viséan - Namurian of Saudi Arabia (Clayton, 1995), Niger (Coquel et al., 1995), Algeria (Lanzoni \& Magloire, 1969; Attar et al., 1980; Clayton \& Loboziak, 1985; Abdesselam-Rouighi \& Coquel, 1997), Libya (Massa et al., 1980), Syria (Ravn et al., 1994).

Crassispora kosankei (Potonié \& Kremp) Bharadwaj 1957 emend. Smith \& Butterworth 1967

Remarks. The sculpture distribution in the studied specimens is slightly denser than in the European ones; this character seems insufficient to establish a new taxon, in agreement with di Pasquo (2002).

Occurrence. Recently recognized in late Namurian rocks of Argentina and widely registered in the Namurian-Westphalian of Europe, U.S.A., and Russia (di Pasquo, 2002).

Bascaudaspora submarginata (Playford) Higgs, Clayton \& Keegan 1988 
Occurrence. Late Devonian - Early Carboniferous of Europe (Van Veen, 1981; Avchimovitch et al., 1988; Loboziak et al., 1994). Early Carboniferous of Canada (Playford, 1964; Utting, 1987a, 1987b), Alaska (Ravn, 1991), Europe (Turnau, 1978; Van der Zwan, 1980a; Higgs et al., 1988; Higgs, 1996), Brazil (Melo \& Loboziak, 2000).

Densosporites anulatus (Loose) Schopf, Wilson \& Bentall 1944 (Figure 1I)

Occurrence. Strunian of France (Coquel \& Deunff, 1977). Late Devonian - Early Carboniferous of Libya (Coquel \& Moreau-Benoit, 1986). Early Carboniferous of U.S.A. (Schopf et al., 1944; Kosanke, 1950), Alaska (Ravn, 1991), Canada (Utting et al., 1989b; Utting, 1991), Spitsbergen (Bharadwaj \& Venkatachala, 1962; Playford, 1963), Brazil (Melo \& Loboziak, 2000). Early - Late Carboniferous of Europe (Smith \& Butterworth, 1967; Turner \& Spinner, 1993), Canada (Braman \& Hills, 1977), Egypt (Kora, 1993).

\section{Kraeuselisporites mitratus Higgs 1975}

Occurrence. Early Carboniferous of Europe (Higgs, 1975; Owens et al., 1976; Keegan \& Feehan, 1981; Higgs \& Clayton, 1984; Higgs et al., 1988), Niger (Loboziak \& Alpern, 1978), Brazil (Loboziak et al., 1998; Melo et al., 1999; Melo \& Loboziak, 2003).

\section{Cristatisporites echinatus Playford 1963}

Occurrence. Late Devonian - Early Carboniferous of Europe (Utting \& Neves, 1971), Brazil (Melo \& Loboziak, 2003). Early Carboniferous of Brazil (Melo \& Loboziak, 2000), Spitsbergen (Playford, 1963), Canada (Playford, 1964), Europe (Combaz \& Streel, 1970; Streel, 1977), Niger (Loboziak \& Alpern, 1978).

\section{Cristatisporites indignabundus (Loose) Potonié \& Kremp 1954 emend. Staplin \& Jansonius 1964}

Occurrence. Early Carboniferous of Alaska (Ravn, 1991). Westphalian B of England (Staplin \& Jansonius, 1964; Smith \& Butterworth, 1967).

\section{Cristatisporites peruvianus Azcuy \& di Pasquo 2005} (Figure 1L)

Remarks. This cavate species bears a cingulum ornamented with biform elements fused in the equatorial region; equator and distal face with galeae and coni are fused forming rugulae which give it a beady appearance. These rugulae may be branched or anastomosed into an irregular reticulum. The proximal exoexine is microgranular or smooth. Comparisons may be consulted in Azcuy \&di Pasquo (2005).

Occurrence. Early Carboniferous of Ireland (Van der Zwan, 1980a; Higgs et al., 1988).

\section{Vallatisporites vallatus Hacquebard 1957}

Remarks. This species is distinguished from others of the genus by having small, discrete coni and grana and less common spines on distal surface. The zona width is narrower than that of Vallatisporites ciliaris (Luber) Sullivan 1964 with a thinner outer portion without a "limbus".

Occurrence. Latest Devonian-Early Carboniferous of Europe (Van der Zwan, 1980a; Van Veen, 1981; Avchimovitch et al., 1988), Brazil (Melo et al., 1999; Melo \& Loboziak, 2003), Libya (Coquel \& Moreau-Benoit, 1986). Early Carboniferous of Brazil (Loboziak et al., 1991; Melo \& Loboziak, 2000), Europe (Sullivan, 1968; Hibbert \& Lacey, 1969; Combaz \& Streel, 1970; Streel, 1977; Keegan, 1977; Clayton et al., 1978; Garrote \& Broutin, 1979; Keegan \& Feehan, 1981; Higgs \& Clayton, 1984; Higgs et al., 1988; Clayton \& Turnau, 1990), USA (Clayton et al., 1998), Canada (Hacquebard, 1957; Playford, 1964; Utting, 1987a; Utting et al., 1989a), Libya (Massa et al., 1980), Morocco (Loboziak et al., 1990). For other previous records of Latest Devonian - Early Carboniferous palynofloras from Euramerica, Brazil and Africa see Playford \& McGregor (1993), and of Late Carboniferous palynofloras from Argentina and Brazil see di Pasquo (2002).

\section{Grandispora debilis Playford 1971}

Occurrence. Early Carboniferous of Australia (Playford, 1971, 1985, 1991; Playford \& Satterthwait, 1988).

\section{Spelaeotriletes balteatus (Playford) Higgs 1996}

Remarks. From the discussions on Spelaeotriletes presented by Higgs et al. (1988) and Playford et al. (2001) it is concluded that the main distinguishing feature of this genus with relation to Grandispora is the presence of discrete and fused, variably apiculate and verrucose elements that form short rugulae. The variability of other features in both genera is considered to be almost the same.

Occurrence. Early Carboniferous of Spitsbergen (Playford, 1963), Europe (Higgs, 1975, 1996; Keegan, 1977; Clayton et al., 1978; Van der Zwan, 1980a; Keegan \& Feehan, 1981; Higgs \& Clayton, 1984; Higgs et al., 1988, 1992), USA (Clayton et al., 1998), Canada (Utting et al., 1989b; Utting, 1991), Alaska (Ravn, 1991), Algeria (Attar et al., 1980), Libya (Massa et al., 1980), Morocco (Loboziak et al., 1990), Brazil (Loboziak et al., 1991; Melo et al., 1999; Melo \& Loboziak, 2003). For other records of Tournaisian-Viséan microfloras from Euramerica, China and Gondwana see Playford et al. (2001).

\section{Spelaeotriletes cf. S. pretiosus (Playford) Utting 1987}

Comparisons. This specimen bears a close similarity to $S$. pretiosus var. bellii (Playford) Utting (1987b, pl. 4, figs. 2-4) in respect of the type and size of the sculpture, but it is more closely spaced. Another comparable species is Spelaeotriletes sp. A Neves \& Belt (1971, plate 2, fig. 14), which is almost identical to the Peruvian specimen except for the diameter of the spore. An imprecise assignment is therefore maintained till more specimens are obtained.

Occurrence. Early Carboniferous of Canada (Playford, 1964; Utting, 1987a, 1987b; Utting et al., 1989a), U.S.A. (Clayton et 
al., 1998), Europe (Neves \& Belt, 1971; Higgs, 1975, 1996; Owens et al., 1977; Keegan, 1977; Clayton et al., 1978; Turnau, 1978; Phillips \& Clayton, 1980; Van der Zwan, 1980a; Keegan \& Feehan, 1981; Welsh \& Owens, 1983; Higgs \& Clayton, 1984; Higgs et al., 1988, 1992; Avchimovitch \& Turnau, 1994), Algeria (Attar et al., 1980), Libya (Massa et al., 1980), Brazil (Melo et al., 1999; Melo \& Loboziak, 2003). For other records of Tournaisian-Viséan microfloras from Euramerica, China and Gondwana see Playford et al. (2001).

\section{Genus Velamisporites Bharadwaj \& Venkatachala 1962}

Remarks. Recently and in agreement with Ravn (1991), di Pasquo et al. (2003) have discussed the status of the genera Rugospora and Velamisporites and concluded that Rugospora is a junior synonym of Velamisporites. This conclusion is followed herein.

\section{Velamisporites minutus (Neves \& Ioannides) Ravn 1991} (Figure 1N)

Basionym. Rugospora minuta Neves \& Ioannides, 1974, pl. 8, figs. 7,8 .

Occurrence. Early Carboniferous of Europe (Neves \& Ioannides, 1974; Turnau, 1978; Phillips \& Clayton, 1980; Van der Zwan, 1980a; Higgs et al., 1988), Libya (Massa et al., 1980), Algeria (Abdesselam-Rouighi \& Coquel, 1997), Niger (Coquel et al., 1995), Canada (Utting, 1980, 1987b, 1991; Utting et al., 1989a), Alaska (Ravn, 1991), Brazil (Loboziak et al., 1991; Melo \& Loboziak, 2003).

\section{Genus Auroraspora Hoffmeister, Staplin \& Malloy 1955}

Remarks. Pseudosaccate spores assigned to Auroraspora are characterized by the following diagnostic characteristics: thick, dark coloured central body; delicate and spongy outer layer; distinction between pseudosaccus and body sometimes poorly defined; trilete mark generally with lips that do not extend beyond the edge of the spore body; exoexine sometimes carrying minute granulose sculpture.

\section{Auroraspora macra Sullivan 1968}

Occurrence. Late Devonian of Belgium (Becker et al., 1974), Brazil (Loboziak et al., 1988). Late Devonian - Early Carboniferous of Europe (Sullivan, 1968; Turnau, 1975, 1978; Keegan, 1977; Van der Zwan, 1980a, 1980b; Higgs et al., 1988; Loboziak et al., 1994), Brazil (Melo \& Loboziak, 2003), Algeria (Coquel \& Latreche, 1989). Early Carboniferous of Bolivia (Azcuy \& Ottone, 1987), Peru (Aliaga López, 1985), Brazil (Loboziak et al., 1991, 1998), Europe (Neves et al., 1972, 1973; Neves \& Ioannides, 1974; Higgs, 1975; Owens et al., 1977; Phillips \& Clayton, 1980; Graham \& Clayton, 1994), Canada (Utting, 1980, 1987a, 1987b; Utting et al., 1989a, 1989b), Australia (Playford, 1971, 1978, 1985, 1991; Playford \& Satterthwait, 1988), Libya (Massa et al., 1980), Egypt (Kora, 1993), Morocco (Loboziak et al., 1990), Niger (Coquel et al., 1995). For other records see Playford (1991).
Endoculeospora gradzinskii Turnau 1975

Remarks. The Peruvian specimens show a diffuse and irregular central body, and the laesurae are not visible. Endoculeospora rarigranulata var. densigranulata Staplin 1960 is closely comparable to this species, but differs in having a more distinct and less dense central body and ornamentation apparently restricted to grana. The features observed in A. macra (without visible ornamentation) and $E$. gradzinskii (with minute ornamentation) appear to confirm the Auroraspora morphon proposed by Van der Zwan (1980b). Occurrence. Strunian of Germany (Hartkopf-Fröder \& Streel, 1994). Latest Devonian - Early Carboniferous of Poland (Turnau, 1975, 1978), Ireland (Van der Zwan, 1980a 1980b; Van Veen, 1981; Higgs et al., 1988), Russia (Avchimovitch et al., 1988).

Colatisporites decorus (Bharadwaj \& Venkatachala) Williams in Neves, Gueinn, Clayton, Ioannides, Neville \& Kruszewska 1973

Remarks and comparisons. The Peruvian specimens show close affinity with the original specimens illustrated by Bharadwaj \& Venkatachala (1962) and Colatisporites decorus variant A of Van der Zwan (1980b). Velamisporites autraliensis (Playford \& Helby) di Pasquo, Azcuy \& Souza 2003 differs in having a densely microfolded-microrugulate exoexine as described by Jones \& Truswell (1992).

Occurrence. Early Carboniferous of Spitsbergen (Bharadwaj \& Venkatachala, 1962), Europe (Neves et al., 1973; Neves \& Ioannides, 1974; Van der Zwan, 1980a, 1980b; Higgs et al., 1988), Alaska (Ravn, 1991), Niger (Loboziak \& Alpern, 1978), Canada (Utting, 1987b, 1991; Utting et al., 1989a, 1989b), Morocco (Loboziak et al., 1990), Brazil (Melo et al., 1999; Melo \& Loboziak, 2000, 2003).

Schopfipollenites ellipsoides (Ibrahim) Potonié \& Kremp 1954 (Figure 1J)

Schopfipollenites acadiensis Utting, 1987b:38, pl. 5, figs. 7-11. Schopfipollenites sp., Melo \& Loboziak, 2003:192, pl. 7, fig. 6. Comparison. Utting (1987b) erected Schopfipollenites acadiensis to include specimens clearly with the same characters as $S$. ellipsoides but somewhat smaller. On the other hand, Taylor (1978) and Taylor \& Rothwell (1982), amongst others, stated that lamellar differentiation, development of distal grooves (which are generally obscured by folding) and grain size are function of maturity and cannot be reliably used for systematic purposes. There are in the literature some other examples of smaller specimens assigned to $S$. ellipsoides like the Peruvian ones, as cited by Coquel et al. (1988) from Libya, Loboziak et al. (1998) from Brazil and di Pasquo (2002) from Argentina. Therefore, the former species is here considered a junior synonym that extends the size range for $S$. ellipsoides.

Occurrence. Widely recorded in microfloras spanning Late Viséan to Stephanian in Euramerica, Middle East (Libya, Saudi Arabia) and Argentina (di Pasquo, 2002). There are also Late 
Viséan records in Brazil (Loboziak et al., 1998; Melo et al., 1999; Melo \& Loboziak, 2003), Libya (Coquel et al., 1988), Saudi Arabia (Clayton, 1995), Russia (Reitlinger et al., 1996) and Canada (Utting, 1987b).

\section{CONCLUDING REMARKS}

This is the second paper ever published on the Early Carboniferous palynology of Peru. The palynoflora of Pongo de Mainique is composed of 55 species, mostly defined at specific level, of which only one resulted a new one (Cristatisporites peruvianus, Figure 1L). The assemblages are generally abundant, diverse and variably preserved and the percentages for the parent plants sources of the groups of palynomorphs are showed in Figure 2. Pteridophyta and Lycophyta dominate the assemblage; Sphenophyta, spores with unknown botanical affinity and reworked spores/ microplankton are subordinated. Scarce acritarchs and other algal cysts (e.g., Veryhachium trispinosum (Eisenack) Deunff, Gorgonisphaeridium sp., Umbellasphaeridium deflandrei (Moreau-Benoit) Jardine et al., Palacanthus sp., Maranhites insulatus Burjack \& Oliveira, Quadrisporites granulatus (Cramer) Ströther) and some typically Devonian spore species like Grandispora sp. cf. G. mammillata Owens and Retispora lepidophyta (Kedo) Playford were considered as reworked. The geographical and stratigraphical distribution, and age range of selected species found in the Ambo Formation, were displayed and discussed in detail in Azcuy \& di Pasquo (2005).

The comparison of the Peruvian palynoflora with others of the Early Carboniferous of the world presented by Azcuy $\&$ di Pasquo (2005) support its correlation to the Cordylosporites magnidictyus Palynozone of the late Viséan of the Amazon Basin, Brazil. Moreover, a greater affinity with Western Europe (66\% of common species), Canada (57\%) and South America (54\%) and a lesser affinity with Africa (45\%) and Australia (30\%) was established based on the number of common species. The Poti Formation in the Parnaíba basin (Brazil, Melo \& Loboziak, 2000) is the most similar association to the Peruvian microflora sharing more than $40 \%$ of its species and another comparable but slightly younger one is recovered from the Kaka Formation (Bolivia, Fasolo et al., 2006). The location of all these assemblages analised in palaeogeographical reconstructions, supports the idea of a ecotonal palaeofloristic province (Paracas Kingdom, Iannuzzi \& Pfefferkorn, 2002), between Gondwana and Euramerica during the late Early Carboniferous, with a palaeolatitudinal position around to $50^{\circ} \mathrm{S}$. The affinity of $57 \%$ with the Viséan associations of Canada is interpreted by its equivalent palaeolatitudinal position $\sim 50 \% \mathrm{~N}$. Noteworthy, some species resulted endemic or exclusive of each Hemispheres, such as Cordylosporites magnidictyus, exclusive species with provincial value in the Late Viséan of Gondwana, which is not present in the Canadian associations, and Schopfipollenites ellipsoides is registered in Canada but it is not present in Europe and Australia during that time. Moreover, the associations of North Africa share with Peru

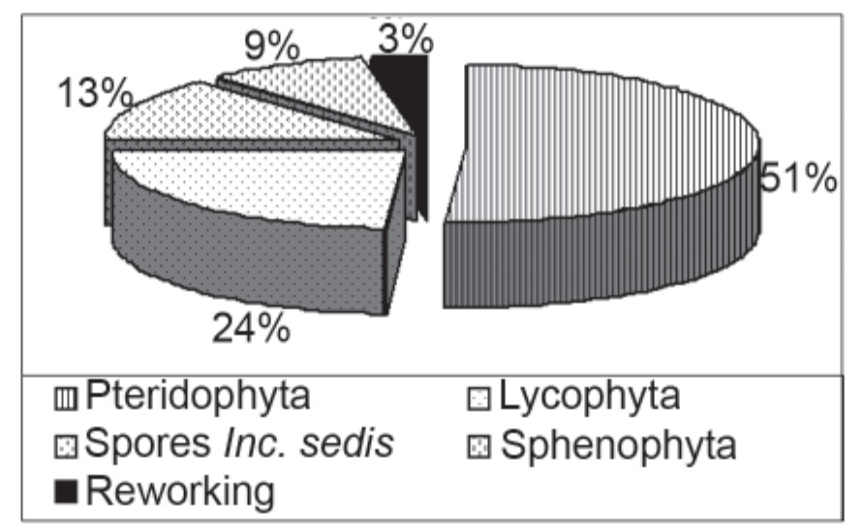

Figure 2. Percentages of major palaeobotanical groups of the Ambo Formation assemblage.

numerous Viséan species but the absence of certain taxa (e.g., Aratrisporites saharensis Loboziak, Clayton \& Owens) from this region also present in Brazil in palaeolatitudes something more losses prevents a closer correlation with Peru. The lesser affinity with palynofloras of Australia would have due to a different palaeolatitudinal position probably more loss added to a relative isolation favouring therefore the endemic character of its palynofloras. Finally, and considering quantitative affinities for the late Viséan only, it is evident that the proportion of species common to the upper part of the Ambo Formation and Europe is restricted (four species) probably as a result of Europe's lower palaeolatitudinal position. On the other hand, in higher palaeolatitudes, preliminary palynological studies carried out in Argentina also show differences with relation to the present palynoflora (Rodríguez Amenábar et al., 2003).

Concerning to the Ambo "Group" in Bolivia, Azcuy \& di Pasquo (2005) suggest that if the Lower Carboniferous sequences presented sufficient lithostratigraphic differences to recognize three formational units, such as Cumaná, Kasa and Siripaca Formations (Díaz Martínez, 1991), it would be desirable to consider the convenience of not using the same established name to designate nondivisible sequences described in other region. On the other hand, some authors (Díaz Martínez, 1999; Suárez Soruco \& Díaz Martínez, 1996; Díaz Martínez et al., 1999) have extended the correlation between the Ambo "Group" to units of the southern Subandean Belt of Bolivia and northern Argentina, i.e., to the Macharetí and Mandiyutí Groups. This attempt at correlation has been rejected on the evidence of palynological data from those groups as also discussed by di Pasquo et al. (2001) and di Pasquo $(2002,2003)$.

\section{ACKNOWLEDGEMENTS}

This work was supported by the national research council of Argentina (CONICET) with grants awarded to C. Azcuy (PIP 2307/00 and PICT R 00313/03). Samples were collected by Valdivia Ampuero and staff of Petroperu S.A. The authors are grateful to the reviewers Henrique Melo and Paulo A. Souza for the improvement of the English text. This paper is a contribution to the IGCP Project 471. 


\section{REFERENCES}

Abdesselam-Rouighi, F. \& Coquel, R. 1997. Palynology du Devonien terminal-Carbonifère Inferieur dans le sud-est du bassin D'Illizi (Sahara algérien). Position des premières lycospores dans la série stratigraphique. Annales de la Société Géologique du Nord, 5:47-57.

Aliaga López, E. 1985. Palinoestratigrafía del Paleozoico, Sección Pongo de Coñec, Cuenca Madre de Dios, sureste del Perú. In: REUNIÓN DE EXPERTOS, 55, 1985. Quito, PETROPERÚ, p. 1-11.

Attar, A.; Fournier, J.; Candilier, A.M. \& Coquel, R. 1980. Etude palynologique du Dévonien terminal et du Carbonifère inférieur du Bassin d'Illizi (Fort Polignac) Algérie. Revue de l'Institut Français du Pétrole, 35:585-619.

Avchimovitch, V.I. \& Turnau, E. 1994. The Lower Carboniferous Prolycospora claytonii zone of western Pomerania and its equivalents in Belorussia and northwestern Europe. Annales Societatis Geologorum Poloniae, 63:249-263.

Avchimovitch, V.I.; Byvscheva, T.V.; Higgs, K.; Streel, M. \& Umnova, V.T. 1988. Miospore systematics and stratigraphic correlation of Devonian-Carboniferous Boundary deposits in the European part of the USSR and western Europe. Courier Forschung-Institut Senckenberg, 100:169-191.

Azcuy, C.L. 1975. Miosporas del Namuriano y Westfaliano de la comarca Malanzán-Loma Larga, Provincia de la Rioja, Argentina. I. Localización geográfica y geológica de la comarca y descripciones sistemáticas. Ameghiniana, 12:1-69.

Azcuy, C.L. \& di Pasquo, M.M. 2005. Early Carboniferous palynoflora of the Ambo Formation, Pongo de Mainique, Perú. Review of Palaeobotany and Palynology, 134(3-4):153-184.

Azcuy, C.L.; di Pasquo, M.M. \& Valdivia Ampuero, H. 2002. Late Carboniferous miospores from the Tarma Formation, Pongo de Mainique, Perú. Review of Palaeobotany and Palynology, Special issue - Stanislas Loboziak, 118:1-28.

Azcuy, C.L. \& Ottone, G. 1987. Datos palinológicos de la Formación Retama en la Encañada de Beu, Río Alto Beni (Bolivia). In: CONGRESO LATINOAMERICANO DE PALEONTOlOGÍA, 4, 1987. Memorias, Santa Cruz de la Sierra, ICI, 1:235-249.

Becker, G.; Bless, M.J.; Streel, M. \& Thorez, J. 1974. Palynology and ostracode distribution in the Upper Devonian and basal Dinantian of Belgium and their dependence on sedimentary facies. Mededelingen Rijks Geologische Dienst, Nieuwe Serie 25:9-99.

Bharadwaj, D.C. \& Venkatachala, B.S. 1962. Spore assemblage out of a Lower Carboniferous shale from Spitsbergen. The Palaeobotanist, 10:17-47.

Braman, D.R. \& Hills, L.V. 1977. Palynology and Paleoecology of the Mattson Formation, Northwest Canada. Bull. Canadian Petroleum Geology, 25:582-630.

Butterworth, M.A. \& Williams, R.W. 1958. The small spore floras of coals in the Limestone Coal Group and Upper Limestone Group of the Lower Carboniferous of Scotland. Transaction Royal Society of Edinburg, 63:352-392.

Césari, S.N. \& Limarino, C.O. 1992. Palinomorfos eocarboníferos en la Formación Cortaderas, provincia de San Juan, Argentina. In: SIMPOSIO ARGENTINO DE PALEOBOTÁNICA Y PALINOLOGÍA, 8, 1991. Actas, Corrientes, UNNE, p. 45-48.

Césari, S.N. \& Limarino, C.O. 1995. Primer registro palinológico de la Formación Malimán (Carbonífero inferior), Cuenca Río Blanco, Argentina. In: CONGRESO ARGENTINO DE
PALEONTOLOGÍA Y BIOESTRATIGRAFÍA, 6, 1995. Actas, Trelew, MEF, p. 77-83.

Clayton, G. 1995. Carboniferous miospore and pollen assemblages from the Kingdom of Saudi Arabia. Review of Palaeobotany and Palynology, 89:115-123.

Clayton, G. \& Loboziak, S. 1985. Early Carboniferous (Early Viséan-Serpukhovian) palynomorphs. Journal of Micropaleontology, 4:83-92.

Clayton, G. \& Turnau, E. 1990. Correlation of the Tournaisian miospore zonation of Poland and the British Isles. Annales Societatis Geologorum Poloniae, 60:45-58.

Clayton, G.; Coquel, R.; Doubinger, J.; Gueinn, K.J.; Loboziak, S.; Owens, B. \& Streel, M. 1977. Carboniferous miospores of western Europe: illustration and zonation. Mededelingen Rijks Geologische Dienst, 29:1-71.

Clayton, G.; Higgs, K.; Keegan, J.B. \& Sevastopulo, G.D. 1978. Correlation of the palynological zonation of the Dinantian of the British Isles. Palinología, 1(núm. extraor.):137-147.

Clayton, G.; Manger, W.L. \& Owens, B. 1998. Mississippian (Lower Carboniferous) miospores from the Cuyahoga and Logan formations of northeastern Ohio, USA. Journal of Micropaleontology, 17:183-191.

Combaz, A. \& Streel, M. 1970. Microfossiles végétaux du Tournaisien inférieur dans le $<$ core-drill $>$ de Brévillers (pas-deCalais, France). In: REUNION DE LA CIMP, COLLOQUE SUR LA STRATIGRAPHIE DU CARBONIFERE, 8, 1970. Comptés Rendus, Liège, 55: 227-240.

Coquel, R. \& Deunff, J. 1977. Sur la découverte de spores du passage Dévonien Carbonifère (Strunien), dan le complex schisteux de la "brèche du Dourduff" (région de Morlaix, Finistère) et sa signification. Comptes Rendus de la Academie de Sciences du París, 285(Serie D):15-18.

Coquel, R.; Doubinger, J. \& Massa, D. 1988. Nouvelles données palynologiques sur l'intervalle Carbonifère Viséen/Moscovien Bassin de Rhadamès (Libye). Comparaison avec les bassins sahariens, appréciation des influences gondwaniennes et euraméricaines. Revue de L'institut Français du Pétrole, 43:3-16.

Coquel, R.; Lang, J. \& Yahaya, M. 1995. Palynologie du Carbonifère du Nord Níger et de la plate-forme saharienne; implications stratigraphiques et paléogéographiques. Review of Palaeobotany and Palynology, 89:319-334.

Coquel, R. \& Latreche, S. 1989. Etude palynologique de la Formation d'Illerene (dévono-carbonifère) du Bassin d'Illizi (Sahara Algerien Oriental). Palaeontographica, Abt. B 212:47-70.

Coquel, R. \& Moreau-Benoit, A. 1986. Les spores des séries struniennes et tournaisiennes de Libye Occidentale. Revue de Micropaléontologie, 29:17-43.

Daemon, R.F. 1974. Palinomorfos-guias do Devoniano Superior e Carbonífero Inferior das bacias do Amazonas e Parnaíba. Anales de la Academia Brasileira de Ciências, 46:549-587.

di Pasquo, M.M. 2002. The Crassispora kosankei - Cystoptychus azcuyi Palynozone from the Upper Carboniferous Tupambi Formation, Tarija basin, northern Argentine. Review of Palaeobotany and Palynology, Special issue, 118:47-75.

di Pasquo, M.M. 2003. Avances sobre palinología, bioestratigrafia y correlación de las asociaciones presentes en los Grupos Macharetí y Mandiyutí, Neopaleozoico de la Cuenca Tarija, provincia de Salta, Argentina. Ameghiniana, 40:3-32.

di Pasquo, M.M.; Azcuy, C.A. \& Souza, P.A. 2003. Palinología del Carbonífero Superior del Subgrupo Itararé en Itaporanga, Cuenca Paraná, Estado de São Paulo, Brasil. Parte 1: sistemática de esporas y paleofitoplancton. Ameghiniana, 40:277-296. 
di Pasquo, M.M.; Azcuy, C.L. \& Starck, D. 2001. Palinología de la Formación San Telmo en la sierra San Antonio, provincia de Salta, Argentina. Ameghiniana, 38:85-98.

Díaz Martínez, E. 1991. Litoestratigrafia del Carbonífero del Altiplano de Bolivia. Revista Técnica del Yacimentos Petroliferos Fiscales de Bolivia, 12:295-302.

Díaz Martínez, E. 1999. Estratigrafia y paleogeografia del Paleozóico Superior del Norte de los Andes Centrales (Bolivia y sur del Perú). In: J. Macharé, V. Benavides, \& S. Rosas (eds.) 75 Aniversario Sociedad Geológica del Perú, p. 19-26.

Díaz Martinez, E.; Vavrdová, M.; Beck, J. \& Isaacson, P.E. 1999. Late Devonian (Famennian) glaciaton in Western Gondwana: evidence from the Central Andes. Abhandlungen der Geologischen Bundesanstalt, 54:213-237.

Dybová, S. \& Jachowicz, A. 1957. Microspores of the Upper Silesian coal measures. Prece Institut Geology, 23:1-328.

Fasolo, Z.; Vergel, M.M.; Oller, J. \& Azcuy, C. 2006. Nuevos datos palinológicos de la Formación Kaka (Viseano Serpukhoviano) en la Encañada de Beu, Subandino Norte de Bolivia. Revista Brasileira de Paleontologia, 9(1):53-62.

Garrote, A. \& Broutin, J. 1979. Le Bassin Tournaisien de Benajarafe (Province de Cordoue, Espagne), géologie et premières données paléobotaniques et palynologiques. In: CONGRÈS NATIONAL DES SOCIÉTÉS SAVANTES, 101, 1976. Actes Sciences, Lille, 1:175-184.

González Amicón, O.R. 1973. Microflora carbónica de la localidad de Retamito, Provincia de San Juan. Ameghiniana, 10:1-35.

Graham, J.R. \& Clayton, G. 1994. Late Tournaisian conglomerates from County Donegal, north-west Ireland; fault-controlled sedimentation and overstep during basin extension. Irish Journal of Earth Sciences, 13:95-105.

Gutiérrez, P.R. \& Césari, S.N. 1988. Nuevas microfloras de la Formación Lagares (Carbonífero), provincia de La Rioja, República Argentina. Ameghiniana, 25:8596.

Hacquebard, P.A. 1957. Plant spores in coal from the Horton Group (Mississippian) of Nova Scotia. Micropaleontology, 3:301324.

Hartkopf-Fröder, C. \& Streel, M. 1994. Late Famennian miospore assemblages from the Bergisch Gladbach-Paffrath syncline, Rhenish slate mountains, Germany. Annales de la Societé géologique de Belgique, 116:333-357.

Hibbert, F.A. \& Lacey, W.S. 1969. Miospores from the Lower Carboniferous Basement Beds in the Menai Straits region of Carnarvonshire, North Wales. Palaeontology, 12:420-440.

Higgs, K.T. 1975. Upper Devonian and Lower Carboniferous miospore assemblages from Hook Head, County Wexford, Ireland. Micropalaeontology, 21:393-419.

Higgs, K.T. 1996. Taxonomic and systematic study of some Tournaisian (Hastarian) spores from Belgium. Review of Palaeobotany and Palynology, 93:269-297.

Higgs, K.T. \& Clayton, G. 1984. Tournaisian miospore assemblages from Maesbury in the eastern Mendips, England. Journal of Micropaleontology, 3:17-28.

Higgs, K.T.; Clayton, G. \& Keegan, J.B. 1988. Stratigraphy and systematic palynology of the Tournaisian rocks of Ireland. Geological Survey of Ireland, Special Paper, 7:1-93.

Higgs, K.T.; Dreesen, R.; Dusar, M. \& Streel, M. 1992. Palynostratigraphy of the Tournaisian (Hastarian) rocks in the Namur Synclinorium, West Flanders, Belgium. Review of Palaeobotany and Palynology, 72:149- 158.

Iannuzzi, R. \& Pfefferkorn, H. 2002. A pre-glacial, warm-temperate floral belt in Gondwana (Late Viséan, Early Carboniferous). Palaios, 17:571-590.
Jones, M.J. \& Truswell, E.M. 1992. Late Carboniferous and Early Permian palynostratigraphy of the Joe Joe Group, southern Galilee Basin, Queensland, and implications for Gondwanan stratigraphy. Journal of Australian Geology \& Geophysics, 13:143-185.

Keegan, J.B. 1977. Late Devonian and Early Carboniferous miospores from the Galley Head - Leap Harbour region of Southwest Ireland. Pollen et Spores, 19:545-573.

Keegan, J.B. \& Feehan, P. 1981. Palynofloras from Tournaisian lacustrine and tidal sequences in Slieve Bloom, Counties Laois and Offaly, Ireland. Geological Journal, 16:271-285.

Kiesling, R. 2002. Código Internacional de Nomenclatura Botánica (Código de Saint Louis). Instituto de Botánica Darwinion and Missouri Botanical Garden Press, 181 p.

Kora, M. 1993. Carboniferous miospore assemblages from the Abu Rodeiyim boreholes, West-Central Sinai, Egypt. Revue de Micropaléontologie, 36:235-255.

Kosanke, R.M. 1950. Pennsylvanian spores of Illinois and their use in correlation. Illinois Geological Survey Bulletin, 74:1-128.

Lanzoni, E. \& Magloire, L. 1969. Associations palynologiques et leurs applications stratigraphiques dans le Dévonien supérieur et Carbonifère inférieur du Grand Erg Occidental (Sahara algérien). Revue de l'Institute Français du Pétrole et Annales de Combustible Liquide, 24:441-469.

Loboziak, S. \& Alpern, B. 1978. Le bassin houllier Viséen d'Agadès (Niger). III Les microspores. Palinología, (núm. Extraord.), 1:55-67.

Loboziak, S.; Melo, J.H.G. \& Streel, M. 1998. Reassessment of Viséan miospore biostratigraphy in the Amazon Basin, northern Brazil. Review of Palaeobotany and Palynology, 104: 143-155.

Loboziak, S.; Streel, M. \& Burjack, M.I.A. 1988. Miospores du Devonien moyen et superieur du Bassin du Parana, Bresil: systematique et stratigraphie. Sciences Géologique Bulletin, 41:351-377.

Loboziak, S.; Streel, M.; Caputo, M.V. \& Melo, J.H.G. 1991. Evidence of West European-defined miospore zones in the uppermost Devonian and Lower Carboniferous of the Amazonas Basin (Brazil). Geobios, 24:5-11.

Loboziak, S.; Streel, M.; Dusar, M.; Boulvain, F. \& De Geyter, G. 1994. Late Devonian-Early Carboniferous miospores from the Menen Borehole, Namur Synclinorium, Belgium. Review of Palaeobotany and Palynology, 80:55-63.

Loboziak, S.; Vachard, D.; Fadli, D. \& Streel, M. 1990. Datation par miospores et Foraminifères du Tournaisien et du Viséen de l'Oued Zemrine (Massif des Mdakra, Maroc). Journal of African Earth Sciences, 11:113-118.

Massa, D.; Coquel, R.; Loboziak, S. \& Taugourdeau-Lantz, J. 1980. Essai de synthèse stratigraphique et palynologique du Carbonifère en Libye Occidentale. Annales de la Societé Géologique du Nord, 99:429-442.

Massa, D. \& Moreau-Benoit, A. 1985. Apport de nouvelles données palynologiques à la biostratigraphie et à la paléogéographie du Dévonien en Libye (sud du Bassin de Rhadamès). Sciences Géologique Bulletin, 38:5-18.

Melo, J.H.G. \& Loboziak, S. 2000. Viséan miospore biostratigraphy and correlation of the Poti Formation (Parnaíba Basin, northern Brazil). Review of Palaeobotany and Palynology, 112:147-165.

Melo, J.H.G. \& Loboziak, S. 2003. Devonian-Early Carboniferous miospore biostratigraphy of the Amazon Basin, Northern Brazil. Review of Palaeobotany and Palynology, 124:131-202.

Melo, J.H.G.; Loboziak, S. \& Streel, M. 1999. Latest Devonian to early Late Carboniferous biostratigraphy of northern Brazil: 
an update. Bulletin of Centre de Recherche Elf-Aquitaine Exploration and Production, 22(1998):13-33.

Menéndez, C.A. \& Azcuy, C.L. 1969. Microflora Carbónica de la localidad de Paganzo, provincia de La Rioja. Parte I. Ameghiniana, 6:77-97.

Naumova, S.N. 1953. Spore-pollen complexes of the Upper Devonian of the Russian Platform and their stratigraphic significance. Transactions of the Institute of Geological Sciences, Academy of Science, SSSR, 143 (Geol. Ser. 60):1-204 [in Russian].

Neves, R. 1961. Namurian plant spores from the Southern Pennines, England. Palaeontology, 4:247-279.

Neves, R. \& Belt, E.S. 1971. Some observations on Namurian and Viséan spores from Nova Scotia, Britain and Northern Spain. In: INTERNATIONAL CONGRESS ON STRATIGRAPHY AND GEOLOGY OF CARBONIFEROUS, 6, 1967. Comptes Rendus, Sheffield, U.S., 3:1233-1248.

Neves, R.; Gueinn, K.J.; Clayton, G.; Ioannides, N. \& Neville, R.S. 1972. A scheme of miospore zones for the British Dinantian. In: INTERNATIONAL CONGRESS ON STRATIGRAPHY AND GEOLOGY OF CARBONIFEROUS, 7, 1971. Comptes Rendus, Krefeld, 1:347-353.

Neves, R.; Gueinn, K.J.; Clayton, G.; Ioannides, N.; Neville, R.S. \& Kruszewska, K. 1973. Palynological correlations within the Lower Carboniferous of Scotland and northern England. Transaction Royal Society of Edinburg, 69:23-70.

Neves, R. \& Ioannides, N. 1974. Palynology of the Lower Carboniferous (Dinantian) of the Spilmersford Borehole, East Lothian, Scotland. Bulletin Geological Survey of Great Britain, 45:73-97.

Owens, B.; Gueinn, K.J. \& Cameron, I.B. 1977. A Tournaisian miospore assemblage from the Altagoan Formation (Upper Carboniferous Sandstone), Draperstown, Northern Ireland. Pollen et Spores, 19:313-324.

Owens, B.; Mishell, D.R.F. \& Marshall, J. 1976. Kraeuselisporites from the Namurian of Northern England. Pollen et Spores, 18: 145156.

Peppers, R.A. 1970. Correlation and palynology of coals in the Carbondale and Spoon Formations (Pennsylvanian) of the Northeastern Part of the Illinois Basin. Illinois State Geological Survey, Bulletin 93:1-173.

Phillips, W.E.A. \& Clayton, G. 1980. The Dinantian clastic succession of Clare Island, County Mayo. Journal of Earth Science Royal Dublin Society, 2:115-135.

Playford, G. 1963. Lower Carboniferous microfloras of Spitsbergen. Part. 2. Palaeontology, 5:619-678.

Playford, G. 1964. Miospores from the Mississippian Horton Group, Eastern Canada. Geological Survey of Canada, Bulletin 107:169.

Playford, G. 1971. Lower Carboniferous spores from the Bonaparte Gulf Basin, Western Australia and Northern Territory. Bureau of Mineral Resources, Geology and Geophysic of Australia, Bulletin, 115:1-105.

Playford, G. 1976. Plant Microfossils from the Upper Devonian and Lower Carboniferous of the Canning Basin, Western Australia. Palaeontographica, Abt.B, 158:1-71.

Playford, G. 1978. Lower Carboniferous spores from the Ducabrook Formation, Drummond Basin, Queensland. Palaeontographica, Abt. B 167:105-160.

Playford, G. 1985. Palynology of the Australian Lower Carboniferous: a review. In: INTERNATIONALCONGRESS ON STRATIGRAPHYAND GEOLOGY OF CARBONIFEROUS, 10,
1983. Comptes Rendus, Madrid, 4: 247-265.

Playford, G. 1988. Lower Carboniferous (Viséan) of the Bonaparte Gulf Basin, northwestern Australia: Part Three. Palaeontographica, Abt. B 208:1-26.

Playford, G. 1991. Australian Lower Carboniferous miospores relevant to extra-Gondwanic correlations: and evaluation. Courier Forschung-Institut Senckenberg, 130:85-125.

Playford, G.; Dino, R. \& Marques Toigo, M. 2001. The upper Paleozoic miospore genus Spelaeotriletes Neves and Owens, 1966, and constituent Gondwanan species. Journal of South American Earth Sciences, 14:593-608.

Playford, G. \& Helby, R. 1968. Spores from a Carboniferous section in the Hunter Valley, New South Wales. Journal of Geological Society of Australia, 15:103-119.

Playford, G. \& McGregor, D.C. 1993. Miospores and organicwalled microphytoplankton of Devonian-Carboniferous boundary beds (Bakken Formation), Southern Saskatchewan: a systematic and stratigraphic appraisal. Geological Survey of Canada, Bulletin 445:1-107.

Playford, G. \& Satterthwait, B. 1985. Lower Carboniferous (Viséan) of the Bonaparte Gulf Basin, northwestern Australia. Part one. Palaeontographica, Abt. B 195:129-152.

Playford, G. \& Satterthwait, B. 1986. Lower Carboniferous (Viséan) of the Bonaparte Gulf Basin, northwestern Australia. Part two. Palaeontographica, Abt. B 200:1-32.

Playford, G. \& Satterthwait, B. 1988. Lower Carboniferous (Viséan) spores of the Bonaparte Gulf Basin, Northwestern Australia: Part three. Palaeontographica, Abt. B 208:1-26.

Playford, G.; Jones, B.G. \& Kemp, E.M. 1976. Palynological evidence for the age of the synorogenic Brewer Conglomerate, Amadeus Basin, Central Australia. Alcheringa, 21:235-243.

Potonié, R. \& Kremp, G.O. 1954. Die Gattungen der Paläozoischen Sporae dispersae und ihre Stratigraphie. Beihefte Geologischen Jahrbuch, Abt. B 69:111-194.

Punt, W.; Blackmore, S.; Nilsson, S. \& Le Thomas, A. 1994. Glossary of pollen and spore terminology. Laboratory of Palaeobotany and Palynology Foundation, 71 p. (Contribution Series 60)

Ravn, R.L. 1991. Miospores of the Kekiktuk Formation (Lower Carboniferous), Endicott Field Area, Alaska North Slope. American Association of Stratigraphic Palynologists Foundation, 173 p. (Contribution Series 27)

Ravn, R.L.; Butterworth, M.A.; Phillips, T.L. \& Peppers, R.A. 1986. Proposed synonymy of Granasporites Alpern 1959 emend. and Cappasporites Urban emend. Chadwick 1983, miospore genera from the Carboniferous of Europe and North America. Pollen et Spores, 28:421-434.

Ravn, R.L.; McPhilemy, B.; Rutherford, M.; Talli, S. \& Bahra, G. 1994. Late Devonian and Early Carboniferous palynostratigraphy and its applications in northeastern Syria. In: M.D. Simmons (ed.) Micropalaeontology and hydrocarbon exploration in the Middle East, Chapman and Hall, p. 5-21.

Reitlinger, E.A.; Vdovenko, M.V.; Gubareva, V.S. \& Shcherbakov, O.A. 1996. European part of the USSR. Lower Carboniferous. In: R.H. Wagner; C.F. Winkler Prins \& L.F. Granados (eds.) The Carboniferous of the World III, InstitutoTécnico GeoMinero de España, p. 23-54.

Rodrígues Amenábar, C.; di Pasquo, M.M. \& Carrizo, H.A. 2003. Datos palinológicos del límite Devónico/Carbonífero em la quebrada Cortaderas, provincia de San Juan, Argentina. In: SIMPÓSIO ARGENTINO DE PALEOBOTÁNICA Y PALINOLOGÍA, 12, 2003. Resúmenes, Buenos Aires, p. 36-37. Schopf, J.M.; Wilson, L.R. \& Bentall, R. 1944. An annotated 
synopsis of Paleozoic fossil spores and the definition of generic groups. Report on Investigation of Illinois State Geological Survey, 91:1-66.

Smith, A.H.V. 1971. Microfossiles Organiques du Paleozoique 4. Les spores 2. Le genre Verrucosisporites par A.H.V. Smith. Commission Internationale de Microflore du Paleozoique (C.I.M.P.), Centre National de la Recherche Scientifique, 4:35-87.

Smith, A.H.V. \& Butterworth, M.A. 1967. Miospores in the coal sems of the Carboniferous of Great Britain. Palaeontology, Special Paper 1:1-324.

Souza, P.A.; Saad, A.R. \& Lima, M.R. 1997. Palinologia dos carvões paleozóicos do Estado de São Paulo. II - O carvão de Monte Mor. Revista do Instituto Geológico, 18:7-21.

Suárez Soruco, R. \& Díaz Martínez, 1996. Léxico Estratigráfico de Bolivia. Revista Tecnica del Yacimentos Petroliferos Fiscales de Bolivia, 17:1-227.

Staplin, F.L. \& Jansonius, J. 1964. Elucidation of some Paleozoic Densospores. Palaeontographica, Abt. B 114:95-117.

Streel, M. 1977. Correlations palynologiques dans le Tournaisien du synclinorium de Namur. Bulletin Société Belge Géologique, 82:397-415.

Sullivan, H.J. 1964. Miospores from the Drybrook Sandstone and associated measures in the Forest of Dean Basin, Gloucestershire. Palaeontology, 7:351-392.

Sullivan, H.J. 1968. A Tournaisian spore flora from the Cementstone Group of Ayrshire, Scotland. Palaeontology, 11:116-131.

Sullivan, H.J. \& Marshall, A.E. 1966. Viséan spore from Scotland. Micropaleontology, 12:265-285.

Taylor, T.N. 1978. The ultrastructure and reproductive significance of Monoletes (Pteridospermales) pollen. Canadian Journal of Botany, 56:3105-3118.

Taylor, T.N. \& Rothwell, G.W. 1982. Studies of seed fern pollen: the development of the exine in Monoletes (Pteridospermales) pollen. American Journal of Botany, 69:570-578.

Turnau, E. 1975. Microflora of the Famennian and Tournaisian deposits from boreholes of northern Poland. Acta Geologica Polonica, 25:505-528.

Turnau, E. 1978. Spore zonation of Uppermost Devonian and Lower Carboniferous deposits of western Pomerania. Mededelingen Rijks Geologische Dienst, 30:1-35.

Turnau, E.; Avchimovitch, B.I.; Byvscheva, T.V.; Clayton, G.; Higgs, K.T. \& Owens B. 1994. Taxonomy and stratigraphical distribution of Verrucosisporites nitidus Playford 1964 and related species. Review of Palaeobotany and Palynology, 81:289-295.

Turner, N. \& Spinner, E. 1993. A palynostratigraphic study of Namurian - Westphalian deltaic sequences of the southern central Pennine Basin, Derbyshire, England. Review of Palaeobotany and Palynology, 77:23-43.

Utting, J. 1980. Palynology of the Windsor Group (Mississippian) in a borehole at Stewiacke, Shubenacadie Basin, Nova Scotia. Canadian Journal of Earth Sciences, 17:1031-1045.

Utting, J. 1987a. Palynostratigraphic investigation of the Albert Formation (Lower Carboniferous) of New Brunswick, Canada. Palynology, 11:73-96.
Utting, J. 1987b. Palynology of the Lower Carboniferous Windsor Group and Windsor-Canso boundary beds of Nova Scotia, and their equivalents in Quebec, New Brunswick and Newfoundland. Geological Survey of Canada, Bulletin, 374:1-93.

Utting, J. 1991. Lower Carboniferous miospore assemblages from the Hart River Formation, Northern Yukon Territory. Geological Survey of Canada, Bulletin 412:81-99.

Utting, J. \& Neves, R. 1971. Palynology of the Lower Limestone Shale Group (Basal Carboniferous Limestone series) and Portishead Beds (Upper Old Red Sandstone) of the Avon Gorge, Bristol, England. Comptés Rendus, Liège, U.L., 55:411-422.

Utting, J.; Keppie, J.D. \& Giles, P.S. 1989a. Palynology and stratigraphy of the Lower Carboniferous Horton Group, Nova Scotia. Geological Survey of Canada, Bulletin, 396:117-143.

Utting, J.; Jachowicz, M. \& Jachowicz, A. 1989b. Palynology of the Lower Carboniferous Emma Fiord Formation of Devon, Axel Heiberg, and Ellesmere Islands, Canadian Artic Archipelago. Geological Survey of Canada, Bulletin, 396:145-171.

Van der Zwan, C.J. 1980a. Aspects of Late Devonian and Early Carboniferous palynology of southern Ireland. III Palynology of Devonian/Carboniferous transition sequences with special reference to the Bantry Bay area, Co. Cork. Review of Palaeobotany and Palynology, 30:165-286.

Van der Zwan, C.J. 1980b. Aspects of Late Devonian and Early Carboniferous palynology of southern Ireland. II. The Auroraspora macra morphon. Review of Palaeobotany and Palynology, 30:133-155.

Van Veen, P.M. 1981. Aspects of Late Devonian and Early Carboniferous palynology of southern Ireland. V. The change in composition of palynological assemblages at the DevonianCarboniferous boundary. Review of Palaeobotany and Palynology, 34:67-98.

Vavrdová, M.; Isaacson, P.E.; Díaz Martinez, E. \& Bek, J. 1993. Devonian - Carboniferous boundary at Lake Titikaka, Bolivia: preliminary palynological results. In: INTERNATIONAL CONGRESS ON STRATIGRAPHY AND GEOLOGY OF CARBONIFEROUS AND PERMIAN, 12, 1991. Comptes Rendus, Buenos Aires, 1:187-200.

Welsh, A. \& Owens, B. 1983. Early Dinantian miospore assemblages from the Caldon Low Borehole, Staffordshire, England. Pollen et Spores, 25:253-264.

Winslow, M.R. 1962. Plant spores and other microfossils from the Upper Devonian and Lower Mississippian rocks of Ohio. United States Geological Survey, Professional Paper 364:1-93.

Wood, G.D.; Groves, J.R.; Wahlman, G.P.; Brenckle, P.L. \& Alemán, A.M. 2002. The paleogeographic and biostratigraphic significance of fusulinacean and smaller foraminifers, and palynomorphs from the Copacabana Formation (Pennsylvanian-Permian), Madre de Dios Basin, Peru. In: L.V. Hills; C.M. Henderson \& E.W. Bamber (eds.) Carboniferous and Permian of the World, Canadian Society of Petroleum Geologists, p. 630-664.

Received in January, 2006; accepted in March, 2006. 